\title{
Modalities of NADP-malic enzyme activities under light and darkness indicate its regulation with reference to $C_{4}$ weed
}

\author{
Bipul Sarkar ${ }^{1,2}$, Arnab Kumar De ${ }^{1}$, Indraneel Saha ${ }^{1}$, Arijit Ghosh ${ }^{1}$, Debabrata Dolui ${ }^{1}$ \& Malay Kumar \\ Adak $^{1^{*}}$
}

${ }^{1}$ Plant Physiology and Molecular Biology Research Unit, Department of Botany, University of Kalyani, Kalyani 741 235, West Bengal, India ${ }^{2}$ Department of Botany, Karimpur Pannadevi College, Karimpur 741 152, West Bengal, India

*Email:mkadak09@gmail.com

\section{ARTICLE HISTORY}

Received: 17 February 2020

Accepted: 15 August 2020

Published: 01 October 2020

\section{KEYWORDS}

NADP-ME

Amaranthus viridis

$\mathrm{C}_{4}$ plants

Redox regulation

Enzyme effectors

\begin{abstract}
NADP - ME is the key enzyme for decarboxylation reactions in $\mathrm{C}_{4} \mathrm{CO}_{2}$ concentration pathways. So, Amaranthus viridis has been evaluated with regards to photosynthetic NADP-malic enzyme for its response under light and darkness. Illumination $\left(1000-1200 \mu \mathrm{Em}^{-2} \mathrm{~s}^{-1}\right)$ for 40 minutes under $2 \mathrm{mM}$ bicarbonate $\left(\mathrm{HCO}_{3}{ }^{-}\right)$sensitivity increased activity by $1.97 \& 3.77$-fold over darkness under $4.0 \mathrm{mM}$ and $0.01 \mathrm{mM}$ malate respectively. Limiting $(0.01 \mathrm{mM})$ and saturated $(4.0 \mathrm{mM})$ malate concentration had significant changes in enzyme activities. The different kinetic parameters indicated had the feedback inhibition under illumination. The activity with the inducer (citrate and succinate) and inhibitor (pyruvate and oxalate) was significant with substrate concentrations. Dithiol had reduced the activity by inhibition of the diminishing effect of light activation treatment. Therefore, NADP-ME is stringently regulated by redox changes with illumination as a key factor. Moreover, the pattern of polymorphic gene expression may be supportive in molecular modulation under light/darkness. This study may support the role of NADP-ME as a biomarker for $\mathrm{C}_{4}$ weed species under oxidative stress through light/darkness.
\end{abstract}

Abbreviations

NADP-ME: nicotinamide adenine dinucleotide phosphate-malic enzyme; HCO3: bicarbonate; CAM: crassulacean acid metabolism; OAA: oxaloacetic acid; DTT: Dithiothreitol; EDTA: ethylenediaminetetraacetic acid; SDS: sodium dodecyl sulphate, BSA: bovine serum albumin; PMSF: phenylmethane sulphonyl fluoride; $\beta$ ME: $\beta$-mercaptoethanol.

\section{Introduction}

For the anaplerotic metabolism in plants, a few oxidative decarboxylation reactions are important. The NADP-malic enzyme (NADP-ME) belongs to a member of NADP oxidoreductase (EC 1.1.1.40) causing decarboxylation of oxaloacetic acid (OAA) as well as oxidation of malate (substrate). The product is pyruvate, reduced NADP $\left(\mathrm{NADPH}+\mathrm{H}^{+}\right)$with the simultaneous release of $\mathrm{CO}_{2}$. The chief function of NADP-ME is in photosynthetic $\mathrm{C}_{4}-\mathrm{CO}_{2}$ concentration mechanism (1). The reduced carbon with different forms is required to donate the carbon residues for the synthesis of biomolecules (2). In $\mathrm{C}_{4}$ plants like Zea mays L., Amaranthus viridis L. and Saccharum officinarum L. NADP-ME is exclusively bound in bundle sheath chloroplast. In CAM plants, it is localised in the cytosol (3). Still, few nonphotosynthetic forms of NADP-ME are also important with varying polymorphisms in different plant tissues.

Apart from malate metabolism, this could provide the reducing potential as $\mathrm{NADPH}+\mathrm{H}^{+}$in different reactions. Therefore, in $\mathrm{C}_{4}$ plants, this enzyme has been a pivotal regulatory step of organic acids metabolism. From the enzymological analysis, NADP$\mathrm{ME}$ is light sensitive, modulated by high $\mathrm{pH}$ and ionic concentration, particularly, under light-grown chloroplast (4-7). On the contrary, in $\mathrm{C}_{3}$ counterparts, this protein is moderately pH-sensitive (optimum

(C) Sarkar et al (2020). This is an open-access article distributed under the terms of the Creative Commons Attribution License, which permits unrestricted use, distribution and reproduction in any medium, provided the original author and source are credited (https://creativecommons.org/licenses/by/4.0/).

To cite this article: Sarkar B, De A K, Saha I, Ghosh A, Dolui D, Adak M K. Modalities of NADP-malic enzyme activities under light and darkness indicate its regulation with reference to $C_{4}$ weed Plant Science Today. 2020;7(4):607-615. https://doi.org/10.14719/pst.2020.7.4.754 
within pH 6.4-7.0). The activity is significantly lesser than $\mathrm{C}_{4}$ species under the same light intensity. In cellular regulation, NADP-ME is sensitive to any regulatory sites of chemical elicitation. Specific inducers or inhibitors are bound on regulatory domains with histidine, arginine and cysteine residues of the enzyme (8). Light is the most influencing physical modulator of NADP-ME. The chemical modifications to alter the activities under varying degrees of irradiance are compatible with other enzymes in the Calvin cycle. Of those later mesophyll chloroplasts sited proteins (pyruvate phosphate dikinase or NADP-malate dehydrogenase) are important. This may suggest the compatibility of NADP-ME for other physiological activities, excluding $\mathrm{C}_{4}$ photosynthesis.

The influence of light is more assured when the enzyme activity increases, relating to seedling greening (9). Therefore, light-induced de-novo synthesis is more confirmed for this protein (10). From other studies in species like maize has been paid attention for precise or short duration-based light-induced NADP-ME activities. More so, in the further investigation to overexpress non-purified leaf extract with more than 55\% increase in activity when irradiated. Therefore, investigations should be customised to revalidate the properties and trend of NADP-ME activities under saturated or limited light sensitivity in $\mathrm{C}_{4}$ plants. We herein performed a simple experiment where a weed (A. viridis), a $\mathrm{C}_{4}$ species was evaluated with its pattern and regulation of leaf extracted NADP-ME activity under light and darkness. The changes in activities, its modalities under light/dark and effects of chemicals (inducers as well as inhibitors) are discussed to characterise the $C_{4}$ weeds with the NADP-ME as a physiological marker.

\section{Materials and Methods}

\section{Plant material and treatments}

One of the $\mathrm{C}_{4}$ weeds, $A$. viridis, belonging to the family Amaranthaceae was collected from natural habitats. Plants were grown in hydroponics with $1 / 4^{\text {th }} \mathrm{MS}$ nutrients medium, pH 7.8 in earthen wire pots for seven days (11). The nutrient solution was renewed every three days interval with proper aeration. Plants in the nutrient solution were kept in polyhouse under the condition of $14 / 10 \mathrm{hr}$ day/night photoperiod, $35 / 30^{\circ} \mathrm{C}$ day/night temperature, $80-85 \%$ relative humidity throughout the experiment. For illumination, plants were kept under active photosynthetic radiation within $1000-1200 \mu \mathrm{Em}^{-2} \mathrm{~s}^{-1}$ photon flux density. For dark adaptation, plants were placed in complete darkness for four hrs (12). The activity was checked with varying concentration of malate as 4.0 and $0.01 \mathrm{mM}$. The data represented three independent replications.

\section{Illumination treatment for induction of enzyme activity}

Leaf samples were collected in a fully grown mature stage from each plant under treatment. However, the samples were done in three replicates from each treatment of solution and also under light \& dark treatment. The uniform sizes $(0.5 \mathrm{~cm}$ in diameter done by cork borer) of leaf discs were done carefully and submerged in $20 \mathrm{ml} 2 \mathrm{mM}$ sodium bicarbonate $\left(\mathrm{Na}_{2} \mathrm{HCO}_{3}\right)$ solution in Petri dishes. The sets were illuminated with fluorescence light of the intensity of 1000-1200 $\mu \mathrm{Em}^{-2} \mathrm{~s}^{-1}$ uninterrupted for $40 \mathrm{~min}$ with two $10 \mathrm{~W}$ CFL. Also, another set was transferred to complete darkness incubation for the same period. For both the sets of light and darkness, the leaf discs were collected, frozen and proceeded for further enzyme extraction and biochemical estimations.

\section{Enzyme extraction and purification}

Leaf samples under light or darkness were ground in liquid nitrogen, then homogenised and dissolved thoroughly with pre-chilled extraction buffer. The buffer composition was $100 \mathrm{mM}$ Tris- $\mathrm{HCl}$ (pH 7.3), 10 $\mathrm{mM} \mathrm{MgCl} 2,10 \mathrm{mM}$ EDTA, $1 \mathrm{mM}$ PMSF, $2 \mathrm{mM} \mathrm{K}_{2} \mathrm{HPO}_{4}$, and $1 \mathrm{mM} \quad \beta$-ME as suggested by a standard procedure (13). The extract was centrifuged (REMI, $\mathrm{KBM}-70$ ) at $12000 \mathrm{rpm}$ at $4{ }^{\circ} \mathrm{C}$ for $15 \mathrm{~min}$ and the pellet was discarded. The protein from the extract was partially purified by $80 \%$ ammonium sulphate precipitation under the cold condition $\left(4^{\circ} \mathrm{C}\right)$ for $4 \mathrm{~h}$. The pellet recovered was separated by dialysis bag (50K MWCO) in the same buffer supplemented with 1 $\mathrm{mM}$ DTT, $10 \mu \mathrm{M}$ BSA, $0.5 \%$ SDS. The protein concentration was determined by Bradford reagent (14) and used for NADP-ME assay.

\section{Assay reaction for NADP-malic enzyme activity}

The assay mixture is made up to $1 \mathrm{ml}$, containing 60 $\mathrm{mM}$ Tris- $\mathrm{HCl}\left(\mathrm{pH}\right.$ 8.0), $10 \mathrm{mM} \mathrm{MgCl}_{2}, 10 \mathrm{mM}$ EDTA, 1 $\mathrm{mM}$ NADP-sodium salt and protein extract $(0.1 \mathrm{ml})$ (13). Two sets of assay mixture were incubated with either saturated $(4.0 \mathrm{mM})$ or limiting $(0.01 \mathrm{mM})$ condition of L-malate as substrate and also inducer/activator (citrate \& succinate) and inhibitor (oxalate \& pyruvate) are used to see their effects. On incubation at room temperature, immediately after the addition of $50 \mu \mathrm{g}$ protein from crude extract and reduction of NADP was read at $340 \mathrm{~nm}$ in a UV-VIS spectrophotometer (Cecil, CE 7200) for $3 \mathrm{~min}$ at 30-sec intervals. The enzyme activity was expressed as $\mathrm{nM}$ $\mathrm{NADPH}$ produced/min/mg protein.

\section{Statistical analysis}

Data were represented as mean \pm SE of three replicates. Variations between treatments were calculated with Duncan's t-test ( $\mathrm{P} \leq 0.05)$. To validate the significant variation among the parameter through each treatment one-way analysis of variance (ANOVA) was performed, and F-values were marked with an asterisk under each level of significance. For statistical analysis SPSS software, IBM-version 26 was used.

\section{Results}

The leaf discs of $A$. viridis were incubated under illumination (1000-1200 $\mu \mathrm{Em}^{-2} \mathrm{~s}^{-1}$ ) supplemented with a $2 \mathrm{mM} \mathrm{Na}_{2} \mathrm{HCO}_{3}$ (pH 8.0). The enzymatic properties of NADP-ME were evaluated under conditions of light and darkness. The concentration of substrate (malate) was used either undersaturated $(4.0 \mathrm{mM})$ or limited (0.01 mM), pH 8.0 as suggested (13). 


\section{Induction of activity of NADP-ME under light}

At the PAR (1000-1200 $\left.\mu \mathrm{Em}^{-2} \mathrm{~s}^{-1}\right)$ there recorded an induction of in-vitro $\mathrm{NADPH}+\mathrm{H}^{+}$oxidation that otherwise denotes NADP-ME activity. Under varying malate concentration, the activity was linear as a function of light and darkness. As compared to darkness, illumination was significantly $(p \leq 0.05)$ inductive while progressing through time for malate concentration of $4.0 \mathrm{mM} \& 0.01 \mathrm{mM}$ (Tab. 1). The
$\mathrm{mM}$ succinate, $5 \mathrm{mM}$ pyruvate and $1 \mathrm{mM}$ oxalate respectively were incubated in independent assay buffer. The comparison was significantly $(p \leq 0.05)$ varied for enzyme activity to both the effectors (activator \& inhibitor) under saturated $(4.0 \mathrm{mM})$ and limiting $(0.01 \mathrm{mM})$ malate concentration (Fig. 3, Fig. 4). The results revealed the role of activators were more inducing at $0.01 \mathrm{mM}$ than $4.0 \mathrm{mM}$ of malate concentration. This recorded, 1.48 \& 1.30 -fold

Table 1. Analysis of variance (by one way) of the different treatments interacted the parameters.

\begin{tabular}{|c|c|c|c|c|}
\hline \multirow{2}{*}{ Parameter } & \multicolumn{2}{|c|}{ Under saturated (4.0 mM) Malate Concentration } & \multicolumn{2}{|c|}{ Under limiting (0.01 mM) Malate Concentration } \\
\hline & Light & Dark & Light & Dark \\
\hline $\begin{array}{l}\text { Time Standardization } \\
\text { (min) }\end{array}$ & $\begin{array}{l}\mathrm{F} \text {-value }=102.514^{* * *} \\
\mathrm{CD}=1.460\end{array}$ & $\begin{array}{l}\text { F-value }=60.550^{* * *} \\
\mathrm{CD}=2.295\end{array}$ & $\begin{array}{l}\text { F-value }=90.907^{* * *} \\
\mathrm{CD}=1.460\end{array}$ & $\begin{array}{l}\text { F-value }=2.430 \\
\mathrm{CD}=1.00\end{array}$ \\
\hline $\begin{array}{l}\mathrm{HCO}_{3}{ }^{-} \text {Conc. (mM) } \\
\text { Standardization }\end{array}$ & $\begin{array}{l}\text { F-value }=36.186^{* * *} \\
\mathrm{CD}=2.323\end{array}$ & $\begin{array}{l}\text { F-value }=0.057 \\
C D=2.692\end{array}$ & $\begin{array}{l}\text { F-value }=16.213^{* * *} \\
\mathrm{CD}=1.123\end{array}$ & $\begin{array}{l}\text { F-value }=0.154 \\
C D=1.487\end{array}$ \\
\hline $\begin{array}{l}\text { NADP-ME activity with } \\
\text { inducer and inhibitor }\end{array}$ & $\begin{array}{l}\text { F-value }=258.867^{* * *} \\
\mathrm{CD}=3.355\end{array}$ & $\begin{array}{l}\text { F-value }=620.799 * * * \\
\mathrm{CD}=1.852\end{array}$ & $\begin{array}{l}\text { F-value }=148.607^{* * *} \\
C D=1.525\end{array}$ & $\begin{array}{l}\text { F-value }=105.626^{* * *} \\
\mathrm{CD}=1.412\end{array}$ \\
\hline
\end{tabular}

activity reached optimum after 40 minutes under illumination (Fig. 1). This showed the time-dependent kinetics of NADP-ME independent to malate concentration. The activity was recorded by $1.97 \&$ 3.77-fold respectively under $4.0 \mathrm{mM}$ and $0.01 \mathrm{mM}$ malate under light over darkness. $\mathrm{HCO}_{3}^{-}$acted as inducer for light-induced enzyme activity and also significantly elevated through the concentration of salts. However, the activity was optimum in light at 2 $\mathrm{mM} \quad \mathrm{HCO}_{3^{-}}$which recorded $37.27 \mathrm{NADPH}$ produced/min/mg proteins. The darkness had hardly any effect on $\mathrm{HCO}_{3}^{-}$concentration for NADP-ME activity (Fig. 2). The induction of optimum activity at $2 \mathrm{mM}$ of $\mathrm{HCO}_{3}^{-}$was $1.39 \& 1.40$-fold under $4.0 \mathrm{mM}$ and $0.01 \mathrm{mM}$ of malate concentration respectively as compared to the darkness.

Effect of activator and inhibitor on the sensitivity of activity under light and darkness:

The regulatory properties of NADP-ME from both the sets of light and darkness were compared, particularly when the assay mixture contains activator or inhibitor. For that two $2 \mathrm{mM}$ citrate, 2 increase for citrate and succinate respectively against normal condition under the light. In addition the enzyme activities were enhanced by $1.40 \& 1.43$-fold with citrate and succinate under light compared to darkness.

Amaranthus viridis responded well with inhibitory effectors like oxalate and pyruvate in the assay process. On illumination of enzyme activity, a significant $(p \leq 0.05)$ changes irrespective of malate concentration $(4.0 \mathrm{mM} \& 0.01 \mathrm{mM})$ was recorded (Fig. 3, Fig. 4). At saturated ( $4.0 \mathrm{mM})$ concentration, the activity declined by $27.60 \%$ over the normal condition, which again reduced by $32.78 \%$ in darkness when oxalate, an inhibitor was used. With pyruvate, another inhibitor, the fall in enzyme activity was almost comparable to oxalate regardless of light and darkness. Interesting to note, for the inhibitors in the assay mixture also significant $(p \leq 0.05)$ variations between them were observed in the regulation of enzyme activity (Tab. 1). Therefore, NADP-ME appeared to be more sensitive to both the inhibitors against the uninhibited condition.

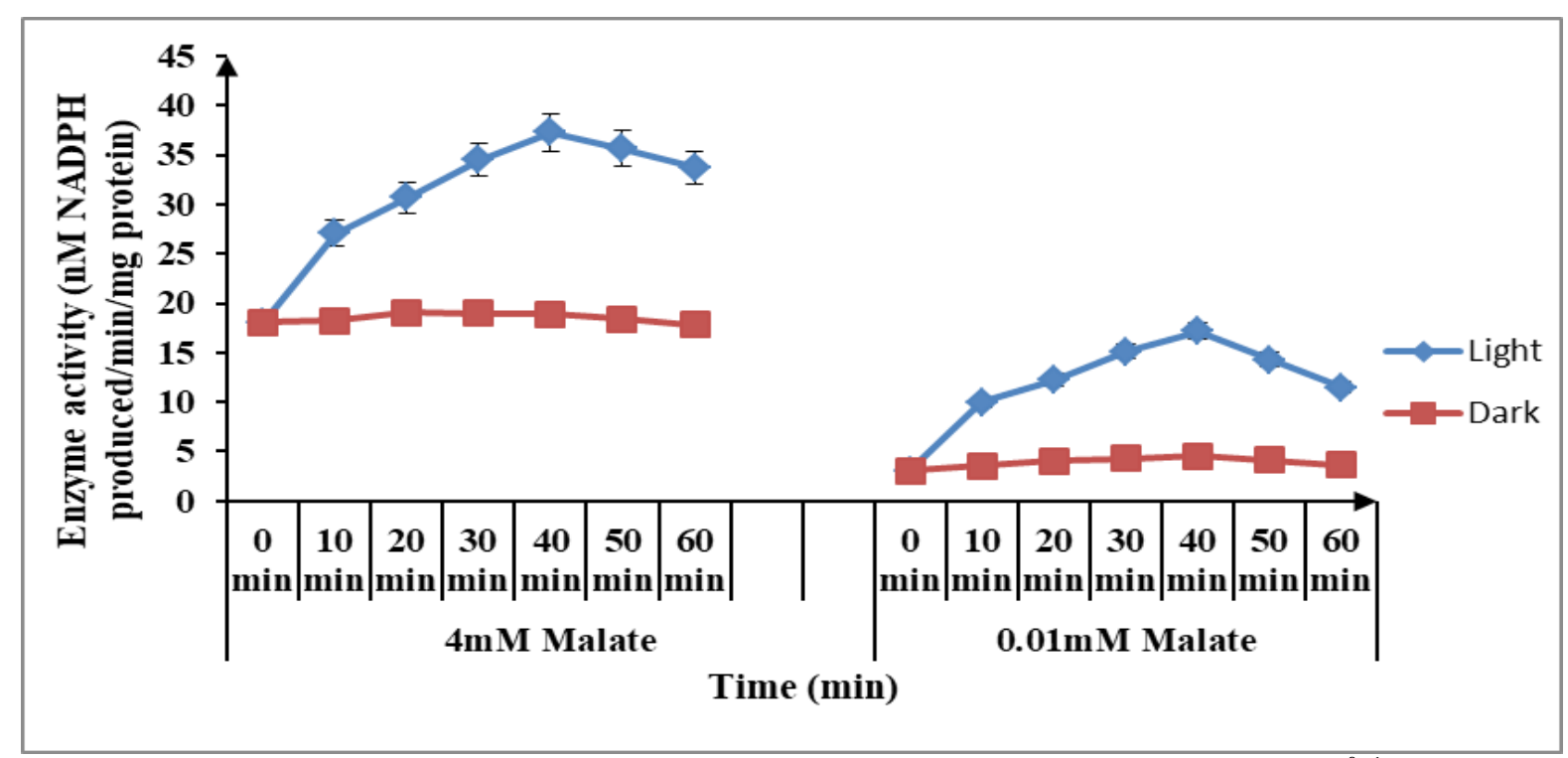

Fig. 1. The trend in enzyme activity of NADP-ME through a varying period (min) of illumination (1000-1200 $\left.\mu \mathrm{Em}^{-2} \mathrm{~s}^{-1}\right) \mathrm{under}^{\mathrm{saturated}}(4$ $\mathrm{mM}$ ) and limiting $(0.01 \mathrm{mM})$ malate concentration. The standardisation was done in the assay mixture with $2 \mathrm{mM} \mathrm{HCO}_{3}{ }^{-}$solution and the mean \pm SE values. 


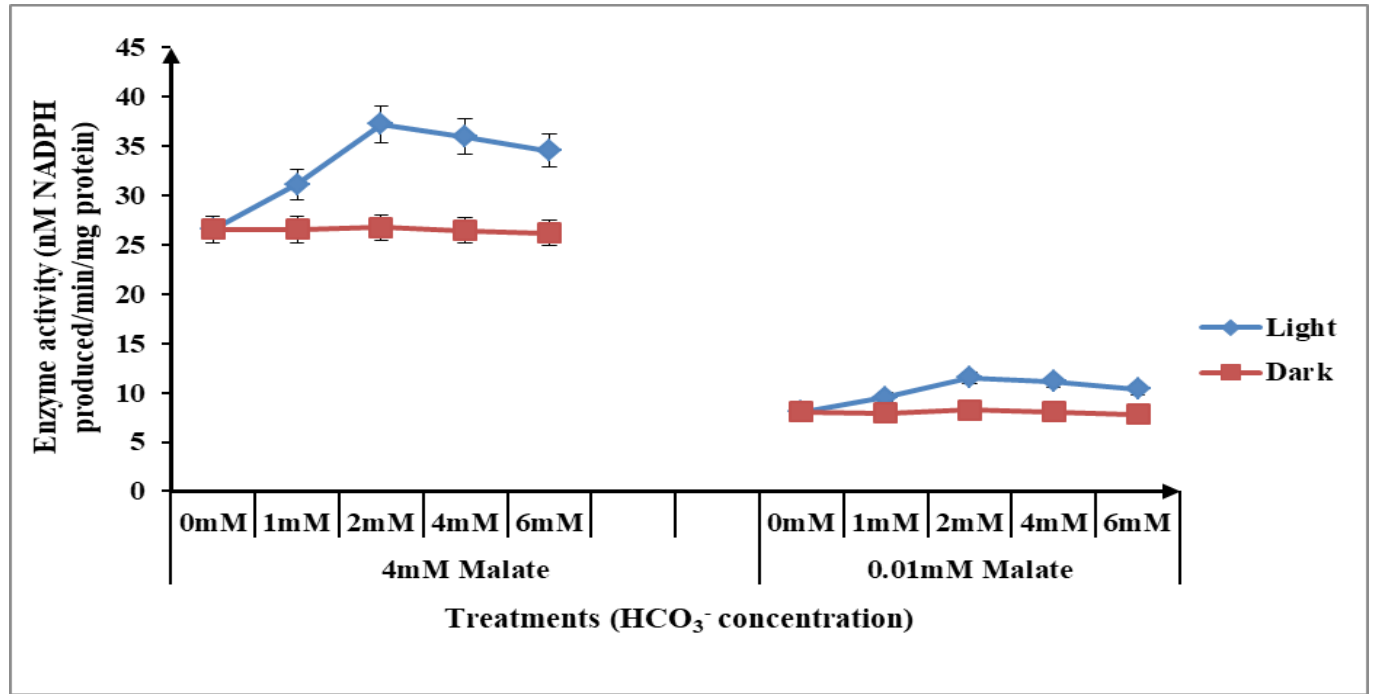

Fig. 2. The activity of NADP-ME under varying $(0,1,2,4,6 \mathrm{mM}) \mathrm{HCO}_{3}{ }^{-}$concentrations. The illumination was maintained at $1000-1200 \mu \mathrm{Em}{ }^{-2} \mathrm{~s}^{-1}$ for $40 \mathrm{~min}$. The enzyme activity was measured in a reaction mixture supplemented with saturated $(4 \mathrm{mM})$ and limiting $(0.01 \mathrm{mM}) \mathrm{malate}$ concentration and the mean \pm SE values.

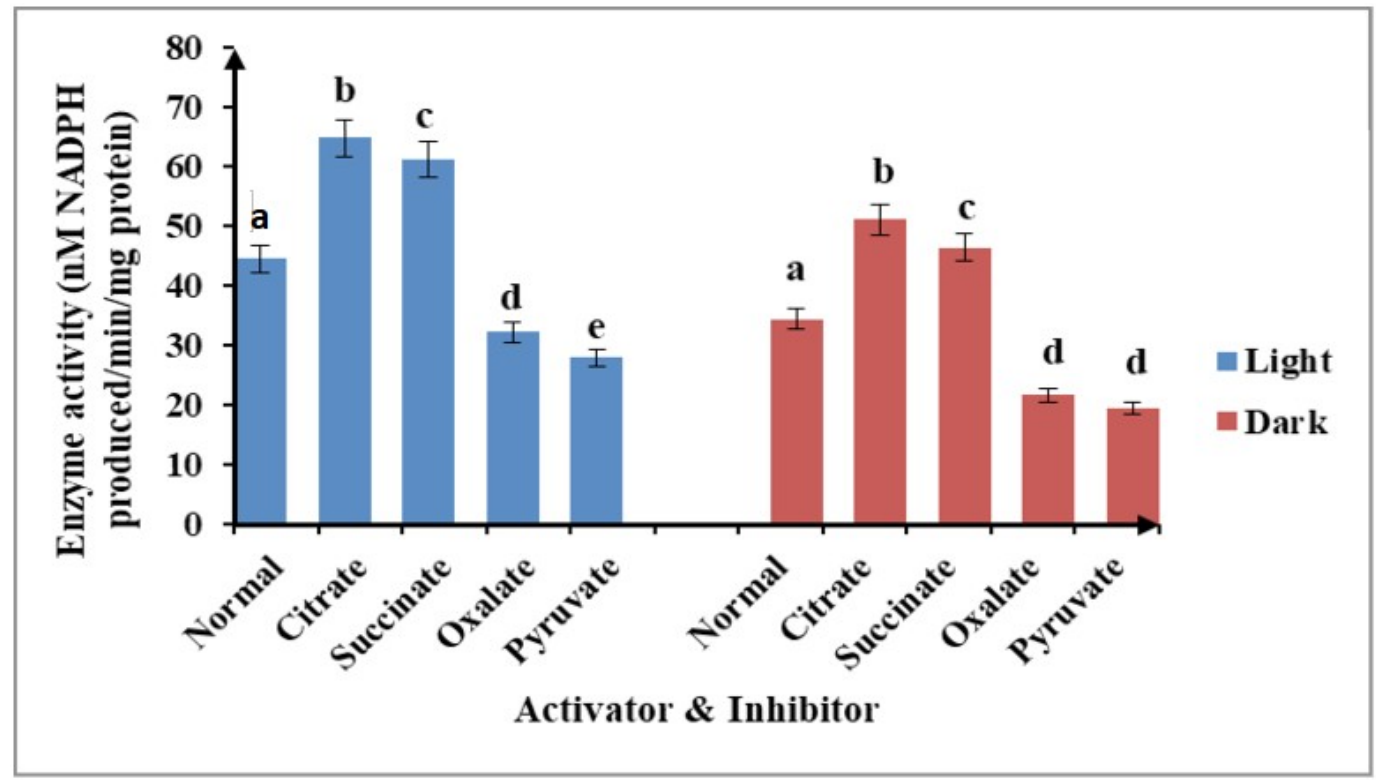

Fig. 3. Effects on NADP-ME activity with various activators (citrate and succinate) and inhibitors (oxalate and pyruvate) incubated with 4.0 $\mathrm{mM}$ malate. The activity was measured at intensity $1000-1200 \mu \mathrm{Em}^{-2} \mathrm{~s}^{-1}$ for $40 \mathrm{~min}$ against darkness and the mean $\pm \mathrm{SE}$ values.

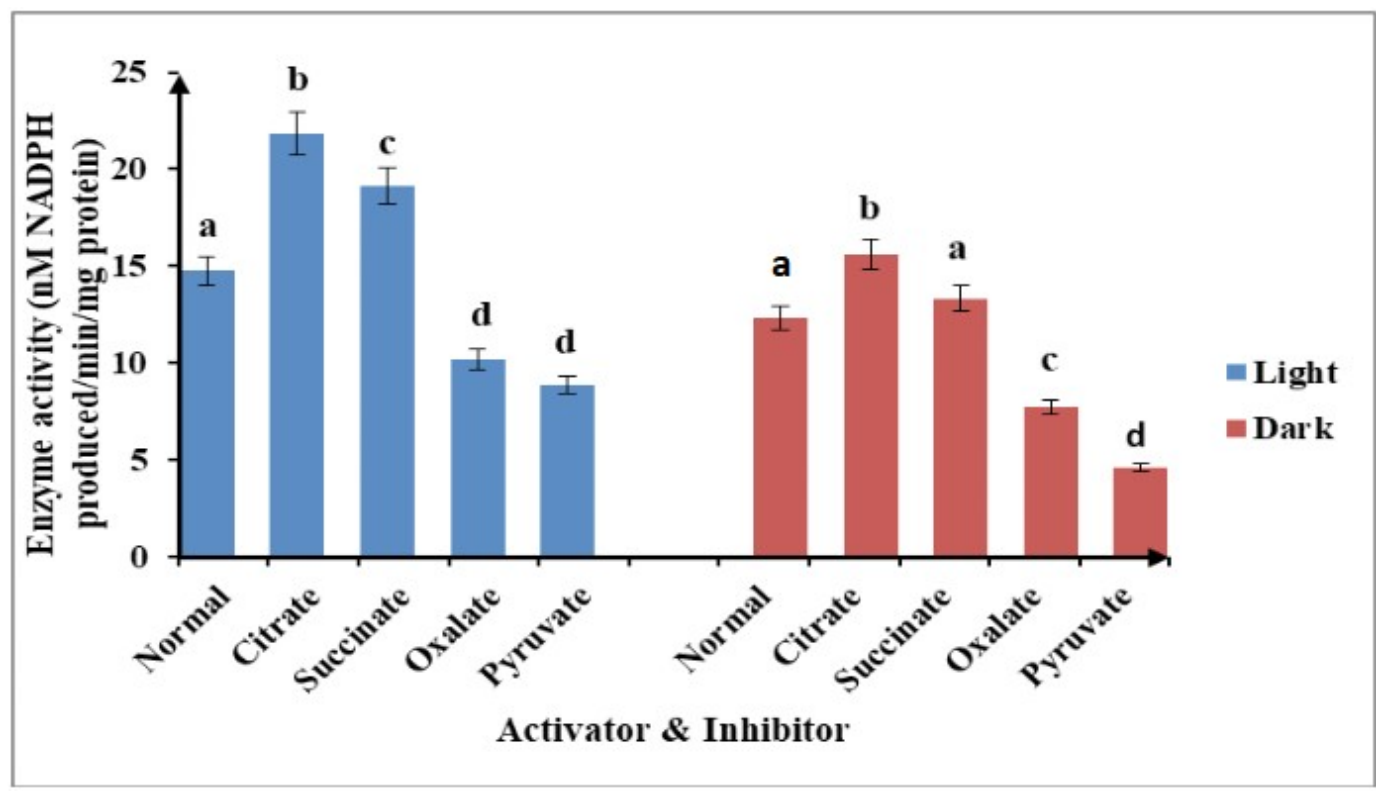

Fig. 4. Effects on NADP-ME activity with various activators (citrate and succinate) and inhibitors (oxalate and pyruvate) incubated with 0.01 $\mathrm{mM}$ malate. The activity was measured at intensity $1000-1200 \mu \mathrm{Em}^{-2} \mathrm{~s}^{-1}$ for $40 \mathrm{~min}$ against darkness and the mean $\pm \mathrm{SE}$ values. 
Therefore, both activator and illumination had a positive role in minimising the dampening of enzyme activity, as herein in the present experiment.

\section{Changes in regulatory properties by DTT application}

Almost all photosynthetic enzymes are lightdependent in regulation; NADP-ME activity also showed distinct modality of regulation. The regulation was more significant when supplemented with $10 \mathrm{mM}$ DTT under light/darkness adaptation (Fig. 5). DTT, a thiol reducing compound added to enzyme extract either with $4.0 \mathrm{mM}$ or $0.01 \mathrm{mM}$ malate concentration, reduced the activity. The results were represented as a ratio of enzyme activity under light and darkness with presence (+) or absence (-) of DTT. Thus light/darkness (L/D) had an opposing trend as a function of malate concentration. At limiting substrate concentration DTT (+) enhanced the activity under L/D by 1.04-fold as compared to DTT (-) (Table 2). On the contrary, the L/D was significantly curtailed by $10.08 \%$ under DTT (-) incubation with saturated $(4.0 \mathrm{mM})$ concentration. more pronounced with the effects of light and darkness on expression. Therefore, light has also an influence for site-specific expression of polymorphic genes as illustrated herein NADP-ME. This was most clarified when densitometric analysis through Gel Analyser software (Gel Analyser 2010a) was done (Fig. 7). Through scan images, the most overexpressed protein of NADP-ME as identified under light was the protein of Band 2. In comparison with the dark, a several-fold overexpression recorded in NADP-ME activity under the light.

\section{Discussion}

Several reports have enriched the modality of regulation of NADP-ME in $\mathrm{C}_{4}$ categories, mostly from crop species. NADP-ME with physiological significance attributes implication of stress responses (15). This is because of the collective involvement of NADP-ME in photosynthetic as well as non-photosynthetic carbon reduction paths. NADP-ME, even with non-photosynthetic form has

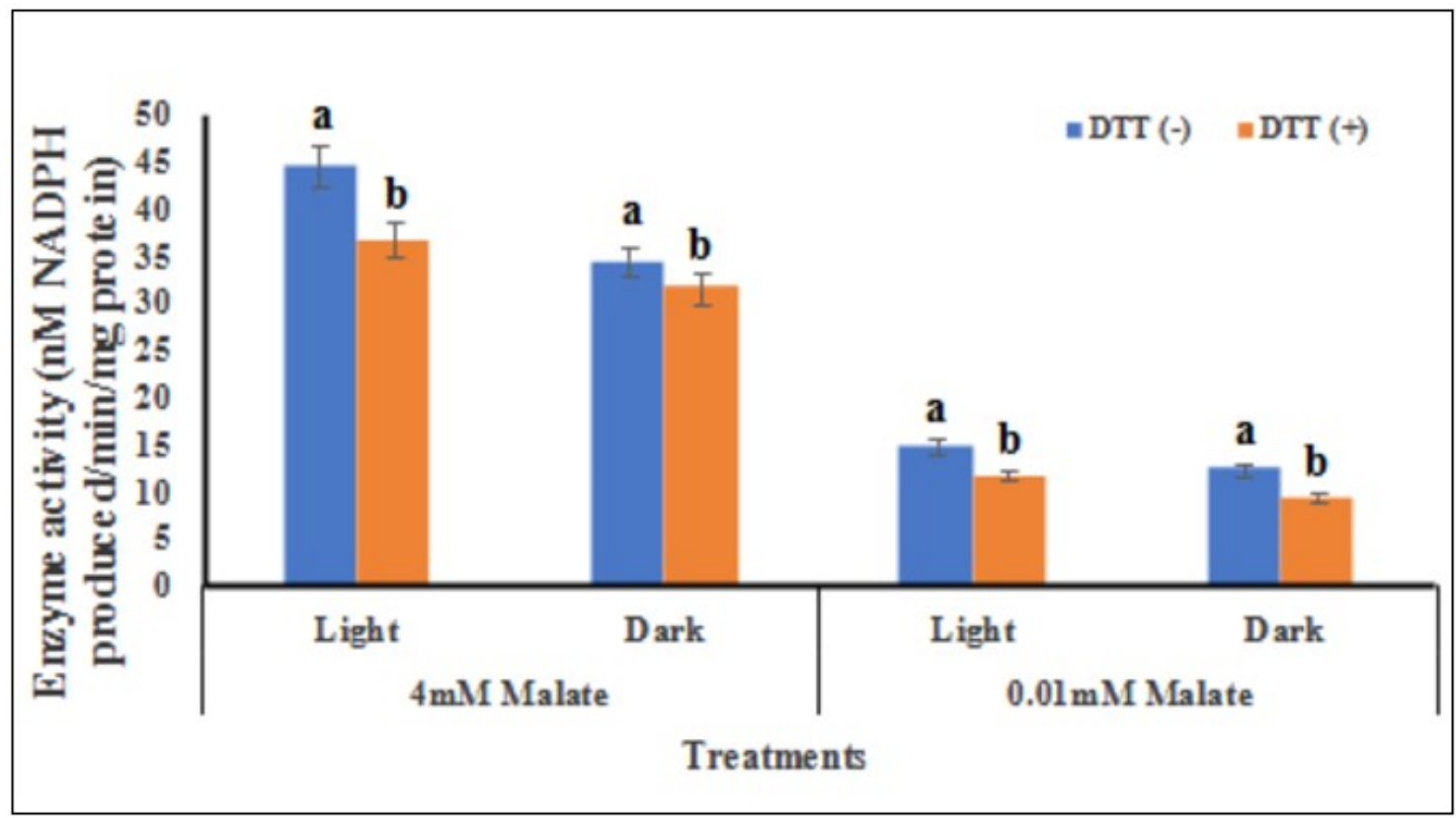

Fig. 5. The changes in the activity of NADP-ME under light (1000-1200 $\left.\mu \mathrm{Em}^{-2} \mathrm{~s}-1\right)$ and darkness during $40 \mathrm{~min}$ in the presence (+) and absence $(-)$ of DTT and the mean \pm SE values.

Therefore, the DTT has a definite role in reducing the activity by thiol reduction of the allosteric site, even ignoring the light/darkness effect on regulation.

\section{Isozymic expression of NADP-ME under light and darkness induction}

A distinct separation of polymorphic bands of NADP-ME has been found through native PAGE (polyacrylamide gel electrophoresis) and bands were significantly varied in expression according to light and darkness (Fig. 6). On saturated condition of malate (4.0 mM) light has a distinct expression as compared to darkness with higher molecular weight polypeptide. This showed that either chloroplastic or organelle bound isozymes, higher molecular weight in nature were mostly variable. Five bands of those, three mostly distinct and concentrated were demarked significantly. These variations were been contexed in stomatal regulation vis-a-vis the osmotic stress tolerance (16). Incidentally, weed species are apparently tolerant to environmental stress rather than mesophytic crop species. This has been expected to involve $\mathrm{CO}_{2}$ concentration path with NADP-ME interference (17). However, significant reports for adaptability, survival and distribution of $\mathrm{C}_{4}$ weeds are few in the background to NADP-ME. This may be more logical when this enzyme activity complements the diversion of reduced carbon from anaplerotic reactions that may support stress tolerance (18). Therefore, it would be interesting to monitor the activities and its regulation of NADP-ME in a weed species like $A$. viridis as presented herein.

The variations in activities of the enzyme NADP-ME was significant and varied with regulatory properties on light and darkness. 
Table 2. The values for changes in the activity of NADP-ME when incubated with presence (+) of $10 \mathrm{mM}$ DTT or its absence (-) and the mean values $^{1}$

\begin{tabular}{|c|c|c|c|c|c|c|}
\hline \multirow[b]{2}{*}{ Treatments } & \multicolumn{3}{|c|}{ Saturated (4 mM) Malate conc. } & \multicolumn{3}{|c|}{ Limiting (0.01 mM) Malate conc. } \\
\hline & Light (L) & Dark (D) & $\mathbf{L} / \mathbf{D}$ & Light (L) & Dark (D) & $\mathbf{L} / \mathbf{D}$ \\
\hline DTT (-) & $44.47 \pm 0.86^{* * *}$ & $34.40 \pm 0.61^{* * *}$ & 1.29 & $14.74 \pm 0.70^{*}$ & $12.33 \pm 0.37^{*}$ & 1.19 \\
\hline DTT (+) & $36.66 \pm 0.65^{* *}$ & $31.62 \pm 0.73^{* *}$ & 1.16 & $11.52 \pm 0.33^{* *}$ & $9.32 \pm 0.33^{* *}$ & 1.24 \\
\hline
\end{tabular}

${ }^{1}$ The activity was measured as nM NADPH produced/min/mg protein from both light (1000-1200 $\left.\mu \mathrm{Em}^{-2} \mathrm{~s}^{-1}\right)$ and darkness. The light treatment was continued for $40 \mathrm{~min}$ in presence of $2 \mathrm{mM} \mathrm{HCO3}$ - under saturated $(4.0 \mathrm{mM})$ and limiting $(0.01 \mathrm{mM})$ of malate. The data represented from three independent replications.

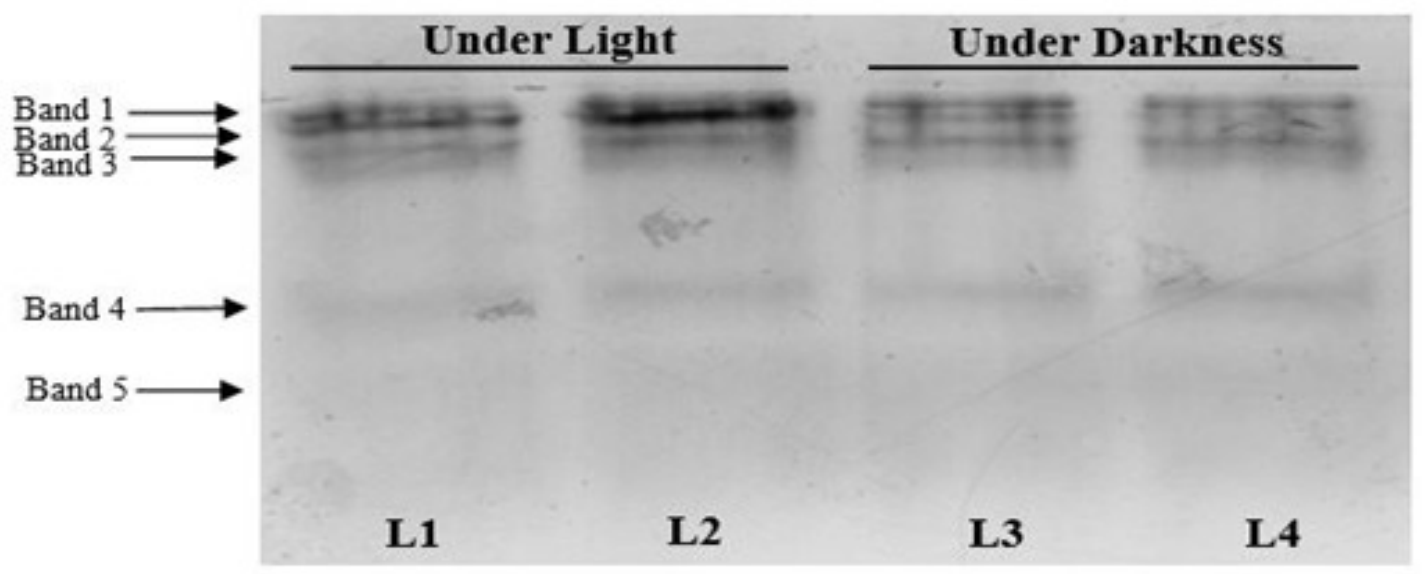

Fig. 6. Expression profile of polymorphism of NADP-ME when separated through $10 \%$ native PAGE under light and darkness induction. Light recorded a distinct overexpression of bands ( 1 \& 2 respectively) under the saturated concentration of malate $(4.0 \mathrm{mM})$ illuminated with 1000-1200 $\mu \mathrm{Em}^{-2} \mathrm{~s}^{-1}$ and darkness for $40 \mathrm{~min}$.

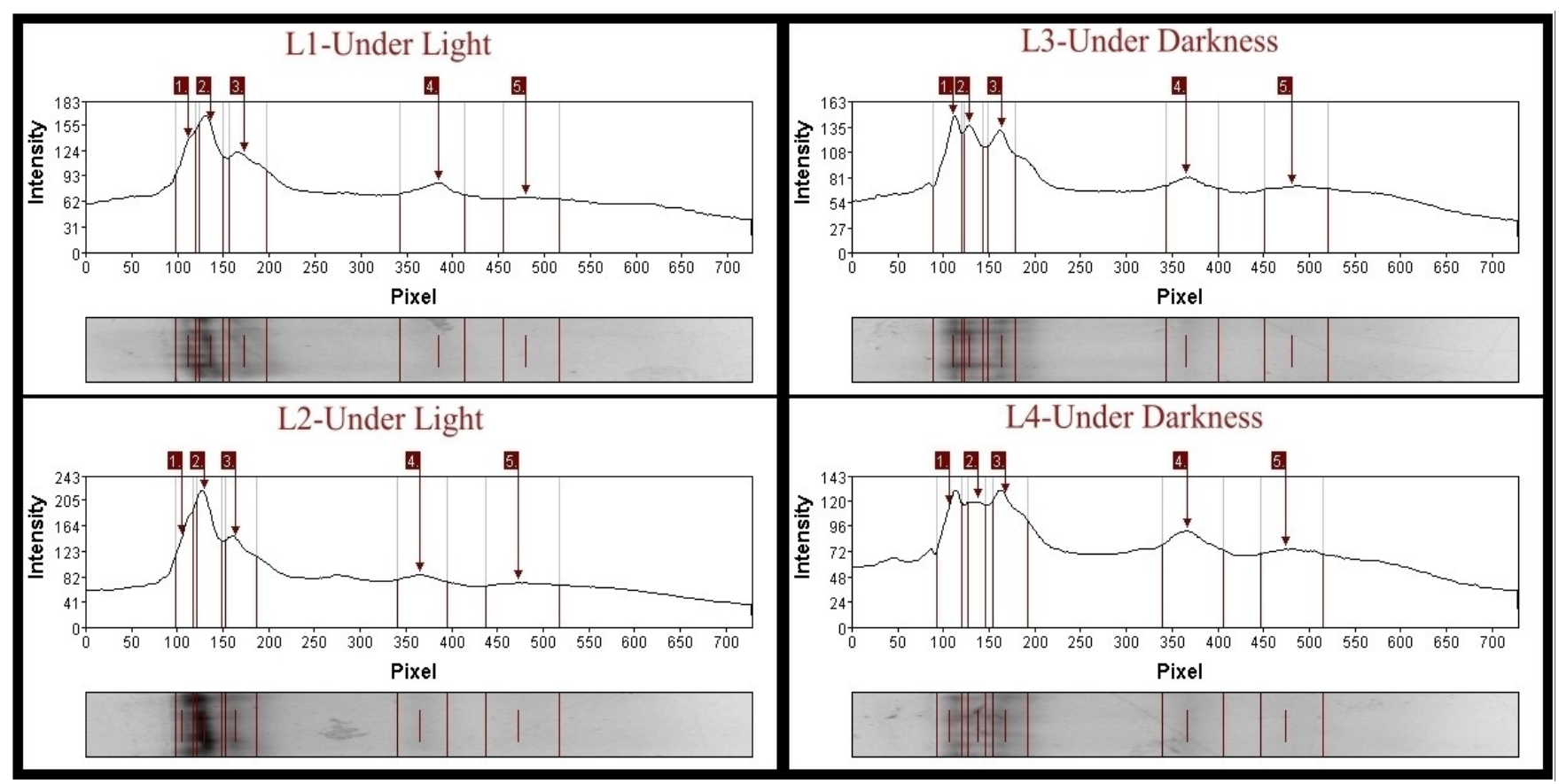

Fig. 7. Densitometric analysis of NADP-ME activity under light and darkness induction. Individual polypeptides recorded 5 bands of those 3 (Band 1,2,3) had significant intensities as compared to others. The light and darkness had the compatible mode of regulation for intensities of polypeptides under the saturated concentration of malate $(4.0 \mathrm{mM})$ as substrate.

Bicarbonate $\left(\mathrm{HCO}_{3}{ }^{-}\right)$was attributed as an effector or inducer, which changed the enzyme kinetics (19). The activity recorded several folds increase under light within the concentration of $2 \mathrm{mM}$. Bicarbonate stabilises the $\mathrm{pH}$ of the assay mixture that has a wider range of sensitivity according to plants genotypes (20). Mostly, the later concerns maize, sugarcane and other crop species. This is relevant with the $\mathrm{C}_{4}$ photosynthesis where the $\mathrm{CO}_{2}$ limitations might have overcome the effects of allosteric inhibitors. In a number of studies, the allosteric modulators of $\mathrm{C}_{4}$ enzymes are commonly regulated with elevated $\mathrm{pH}$ accompanied by high irradiance (21). The enrichment of $\mathrm{CO}_{2}$ from a pathway where NADP-ME acts the decarboxylating reactions in both $\mathrm{C}_{4}$ and $\mathrm{C}_{3}$ species is important. In general, the $\mathrm{C}_{4}$ organic acids from mesophyll tissues may be transferred into bundle sheath cells fallowing 
oxidative decarboxylation. Later is required to concentrate the $\mathrm{CO}_{2}$ within RuBP carboxylase active site to balance the reducing equivalents (NADPH $+\mathrm{H}^{+} /$ $\mathrm{NADP}^{+}$). This is essentially required in the homeostasis of oxidative/reductive redox to resist the disintegration of biomolecules through oxidative stress. $\mathrm{C}_{4}$ species has been favoured to modulate the oxidative exposure within tissues more with the maintenance of reduced state (22). The activity of NADP-ME from its time kinetics had more incline to substrate (malate) saturation under the light. The dark inhibition of any regulatory sites with possible changes either through redox, dissociation of oligomers or addition of $\mathrm{Pi}$ is common as referred with few species (23).

It could be speculated that the elevated concentration in $\mathrm{CO}_{2}$ in the bundle sheath is responsible for feedback regulation to the light induction of NADP-ME (24). This was also illustrated in $A$. viridis in the present experiment. The photoactivation has not much been clearly understood. Still, a fall in activities of the enzyme with pyruvate as well as oxalate is proportional to the concentrations of those. Likely, cytosolic pyruvate may be increased and exceeds the threshold value of $5 \mathrm{mM}$, and that could be toxic, as in other $\mathrm{C}_{4}$ species through pyruvate sensitivity of NADP-ME (25). Undoubtedly, pyruvate concentration acts as a negative effector to the regulatory sites of NADP-ME. The $\mathrm{HCO}_{3}^{-}$concentration must be critical in the bundle sheath cells above the ambient, and the concentration $2 \mathrm{mM}$ being an inducer for the enzyme activity. Therefore, it would be no less to speculate that NADP-ME has shown resistance under the high level of $\mathrm{HCO}_{3}^{-}\left(\approx \mathrm{CO}_{2}\right)$ as well as pyruvate. Thus, the increase in activities of NADP-ME might have directly responded to the $\mathrm{HCO}_{3}^{-}$simulation regardless of concentration variations. It was also evaluated for the sensitivity of pyruvate like substances for feedback inhibition of the enzyme. This was illustrated in maize with a higher value of $\mathrm{K}_{\mathrm{i}}$ for the pyruvate (26). This might have been due to a compatible sensitivity with other $\mathrm{C}_{4}$ enzymes as that of $A$. viridis in the present experiment. Similarly, the most important enzyme for carboxylation in $\mathrm{C}_{4}$ species like phosphoenolpyruvate carboxylase (PEPC) has equal sensitivity/regulation on illuminated leaves. Even in $\mathrm{C}_{3}$ species, the influence of light has markedly been evident for other enzymes of nitrogen reduction, sucrose metabolism etc. (27). Therefore, the extent of feedback inhibition would be a general trait of the main enzyme in photosynthetic carbon reduction, and may by post-translational modification. So, the PEPC is an important enzyme for anaplerotic pathways in carbon metabolism for both of its $\mathrm{C}_{4}$ and $\mathrm{C}_{3}$ cycle. The citrate and succinate as activator recorded the compatible pattern in the induction of enzyme activity. This also established the functioning of the enzyme in a concomitant manner to varying concentrations $(4.0 \mathrm{mM}$ and 0.01 $\mathrm{mM}$ ) of malate.

The post-translational amendment in $\mathrm{C}_{4}$ enzyme involves phosphorylation/dephosphorylation of regulatory sites, dissociation/oligomerisation of allosteric sites, changes in redox of sulfhydryl/dithiol ligands etc. (28). Sucrose phosphate synthase, starch phosphorylase, phosphoenolpyruvate carboxykinase (PEPCK) are offered with all possibilities under light-mediated changes in redox. Still, NADP-ME, as observed in the present experiment with $A$. viridis, is subjected to regulation by DTT. Thus, a sharp change in activities was significantly correlated with DTT application in a concomitant manner with malate as substrate. Similar results also interpreted in other $\mathrm{C}_{4}$ plants through reduction of $-\mathrm{S}-\mathrm{S}$ - of amino acids at the regulatory site for induction (29). DTT could dampen the light induction any way by over folded enzyme activities, however, in a dark condition also. Therefore, weed species like $A$. viridis would be more flexible for adaptation in photo-inhibition through reduced thiols, oligomerisation of the enzyme. This probably may give a clue about varied ecological distributions of weeds under oversaturated irradiance. This also would be a possibility to include all the weeds, however, not necessary the $\mathrm{C}_{4}$, as invasive sun plants (a plant groups which grows normally in sunny habitat) groups. This was more evident even in enzymes like malate dehydrogenase, fructose 1, 6-bis phosphatase etc. in other $\mathrm{C}_{4}$ species where NADP serves as coenzyme. The tolerance to weed species from various abiotic stresses resulting in the oxidative burst has an option to maintain the steady-state $\mathrm{C}_{4}$ photosynthesis. These essentially grant NADP-ME as a key regulatory enzyme to sustain photosynthetic rate even under saturated irradiance $(30,31)$.

The present results indicated the isoforms of NADP-ME differed in their electrophoretic mobilities; however, significantly varied under light and darkness. NADP-ME in $\mathrm{C}_{4}$ plant species is represented by the gene family with smaller sizes. A. viridis in the present case, representing by at least three possible isoforms, distinctly varied with light and dark exposure. The light-mediated overexpression of the polypeptides would be involvement in light regulatory elements in promoter sites. Specific light regulatory elements have been identified which perceiving the signal to regulate the gene induction (32). Along with light induced $\mathrm{H}^{+}$transfer in stroma lumen, may be linked with the alkalinity of the $\mathrm{pH}$ with $\mathrm{HCO}_{3}^{-}$induction (33). The variations with $\mathrm{pH}$ dependence in differential gene expression for NADP-ME like other $\mathrm{C}_{4}$ proteins are quite common.

Oxidative stress is manifested by the improper utilisation of light energy essential for cellular pathways. Thereafter, its balance in the ratio of reduced to oxidative state causes over reduced oxygen and its transformation into active/reactive oxygen species (ROS) (34). So, a plant species tolerant to oxidative degeneration would be maintaining a stable proportion of reduced to oxidised redox through some key enzymatic pathways (35). From other $\mathrm{C}_{4}$ species, NADP-ME also reported to be most important in complementation of $\mathrm{CO}_{2}$ enrichment under stress condition (3). $A$. viridis in the present experiment reported the equivalent nature of responses through light and darkness treatment for enzyme activity. This is more prevalent in reactions with limited and 
saturated malate concentrations. The $\mathrm{HCO}_{3}{ }^{-}$induced faster saturation with malate at the active site would be the possible explanation in $A$. viridis also as that found in other $\mathrm{C}_{4}$ species.

\section{Conclusion}

Despite a significant increase in NADP-ME activities under light, the mode of activities was variable according to allosteric effectors. The flow of carbon from the organic acid pool (like citrate and succinate) and its direct impact on NADP-ME would supplement in decarboxylation reactions. This is evident from other studies to sustain the $\mathrm{C}_{4}$ carbon concentration paths under abiotic stresses subjected to water deficits. A. viridis is ecologically quite versatile to adapt to environmental harshness, including depleted soil moisture, an abundance of metals, excess irradiation etc. Therefore, $\mathrm{C}_{4}$ weeds like $A$. viridis may accomplish better biomass accumulation to sustain the carbon concentration; it can exercise the stress tolerance mechanism. The $\mathrm{CO}_{2}$ concentration mechanism in $\mathrm{C}_{4}$ paths is marked with few enzymes being NADP-ME the predominant. So, NADP-ME may serve a better screening index for oxidative stress tolerance under such a condition even with weed species. Further investigation would suffice the regulations of enzyme activity in lightinduced phenomenon at the molecular level.

\section{Acknowledgements}

This work is acknowledged for financial support from University Grant Commission (UGC), Government of India through NET JRF Fellowship scheme to the first author and this work is also supported by DST-PURSE II Program applicable to University of Kalyani.

\section{Authors' contributions}

BS carried out all the experiments. AKD formatted the manuscript. IS and AG did the statistical analysis. DD helps in collecting data. MKA designed, hypothesised the experiment and overall wrote the manuscript.

\section{Conflict of interests}

The authors declare that they have no conflict of interests.

\section{References}

1. Chen Q, Wang B, Ding H, Zhang J, Li S. The role of NADP-malic enzyme in plants under stress. Plant Science. 2019;281:206-12. https://doi.org/10.1016/j.plantsci.2019.01.010

2. Amend JP, McCollom TM. Energetics of biomolecule synthesis on early Earth. ACS Publications. 2009;63-94.

3. Drincovich MF, Casati P, Andreo CS. NADP-malic enzyme from plants: a ubiquitous enzyme involved in different metabolic pathways. FEBS letters. 2001;490(1-2):1-6. https://doi.org/10.1016/S0014-5793(00)02331-0
4. Romanowska E, Buczyńska A, Wasilewska W, Krupnik T, Drożak A, Rogowski P, Parys E, Zienkiewicz M. Differences in photosynthetic responses of NADP-ME type $\mathrm{C}_{4}$ species to high light. Planta. 2017; 245(3):641-57. https://doi.org/10.1007/s00425-016-2632-1

5. De AK, Sarkar B, Saha I, Ghosh A, Dey N, Adak MK Physiological characterisation of NADP-malic enzyme activity under 2,4-D toxicity in an aquatic fern, Azolla pinnata R.Br. African Journal of Plant Science. 2018; 12(9): 208-214. https://doi.org/10.5897/AJPS2018.1666

6. Asami S, Inoue $\mathrm{K}$, Matsumoto $\mathrm{K}$, Murachi A, Akazawa $\mathrm{T}$. NADP-malic enzyme from maize leaf: Purification and properties. Archives of Biochemistry and Biophysics. 1979; 194(2):503-10. https://doi.org/10.1016/0003-9861(79)90645-3

7. Holaday AS, Lowder GW. Effect of $\mathrm{pH}$ on the Kinetic Parameters of NADP-Malic Enzyme from a C4Flaveria (Asteraceae) Species. Plant physiology. 1989; 90(2):401-05. https://doi.org/10.1104/pp.90.2.401

8. Agarwal S, Sairam RK, Srivastava GC, Tyagi A, Meena RC. Role of ABA, salicylic acid, calcium and hydrogen peroxide on antioxidant enzymes induction in wheat seedlings. Plant Science. https://doi.org/10.1016/j.plantsci.2005.05.004

9. Manivannan A, Soundararajan P, Halimah N, Ko $\mathrm{CH}$, Jeong BR. Blue LED light enhances growth, phytochemical contents and antioxidant enzyme activities of Rehmannia glutinosa cultured in vitro. Horticulture, Environment and Biotechnology. 2015;56(1):105-13. https://doi.org/10.1007/s13580-015-0114-1

10. Buczynska A, Wasilewska W, Drozak A, Romanowska E. Structural organisation of photosynthetic apparatus in mesophyll and bundle sheath chloroplasts of $\mathrm{C}_{4}$ plants of NADP-ME subtype. BioTechnologia. Journal of Biotechnology Computational Biology and Bionanotechnology. 2013;94(3):317-25

11. Murashige T, Skoog F. A revised medium for rapid growth and bio assays with tobacco tissue cultures. Physiologia Plantarum. 1962;15(3):473-97.

12. Force L, Critchley C, van Rensen JJ. New fluorescence parameters for monitoring photosynthesis in plants. Photosynthesis Research. 2003;78(1):17-33. https://doi.org/10.1023/A:1026012116709

13. Murmu J, Chinthapalli B, Raghavendra AS. Light activation of NADP malic enzyme in leaves of maize: marginal increase in activity, but marked change in regulatory properties of enzyme. Journal of Plant Physiology. 2003;160(1):51-56. https://doi.org/10.1078/0176-1617-00844

14. Bradford MM. A rapid and sensitive method for the quantitation of microgram quantities of protein utilising the principle of protein-dye binding. Analytical Biochemistry. 1976;72(1-2):248-54. https://doi.org/10.1016/00032697(76)90527-3

15. Farooq M, Hussain M, Wahid A, Siddique KH. Drought stress in plants: an overview. In Plant responses to drought stress Springer, Berlin, Heidelberg. 2012. p. 1-33. https://doi.org/10.1007/978-3-642-32653-0_1

16. Hyskova VD, Miedzinska L, Dobra J, Vankova R, Ryalava H. Phosphoenolpyruvate carboxylase, NADP-malic enzyme and pyruvate, phosphate dikinase are involved in the acclimation of Nicotiana tabacum L. to drought stress. Journal of Plant Physiology. https://doi.org/10.1016/j.jplph.2013.10.017 2014;171(5):19-25.

17. Patterson DT. Comparative ecophysiology of weeds. Weed Physiology: Volume I: Reproduction and Ecophysiology. 2018; 18:15.

18. Moradi P, Ford-Lloyd B, Pritchard J. Metabolomic approach reveals the biochemical mechanisms underlying drought stress tolerance in thyme. Analytical Biochemistry. 2017;527:49-62. https://doi.org/10.1016/j.ab.2017.02.006

19. Pocker Y, Miksch RR. Plant carbonic anhydrase. Properties and bicarbonate dehydration kinetics. Biochemistry. 1978, 17(6):1119-25

20. Bie Z, Ito T, Shinohara Y. Effects of sodium sulfate and sodium bicarbonate on the growth, gas exchange and mineral 
composition of lettuce. Scientia Horticulturae. 2004;99(34):215-24. https://doi.org/10.1016/S0304-4238(03)00106-7

21. Wand SJ, Midgley GF, Stock WD. Growth responses to elevated $\mathrm{CO}_{2}$ in NADP-ME, NAD-ME and PCK $\mathrm{C}_{4}$ grasses and a $\mathrm{C}_{3}$ grass from South Africa. Functional Plant Biology. 2001; 28(1):13-25. https://doi.org/10.1071/PP99104

22. Nayyar H, Gupta D. Differential sensitivity of $C_{3}$ and $C_{4}$ plants to water deficit stress: association with oxidative stress and antioxidants. Environmental and Experimental Botany. 2006 58(1-3):106-13. https://doi.org/10.1016/j.envexpbot.2005.06.021

23. Puga MI, Rojas-Triana M, de Lorenzo L, Leyva A, Rubio V, PazAres J. Novel signals in the regulation of $\mathrm{Pi}$ starvation responses in plants: facts and promises. Current Opinion in Plant Biology. 2017;39:40-49. https://doi.org/10.1016/j.pbi.2017.05.007

24. Pengelly JJ, Tan J, Furbank RT, von Caemmerer S. Antisense reduction of NADP-malic enzyme in Flaveria bidentis reduces flow of $\mathrm{CO}_{2}$ through the $\mathrm{C}_{4}$ cycle. Plant Physiology. 2012; 160(2):1070-80. https://doi.org/10.1104/pp.112.203240

25. Ohnishi JI, Kanai R. Pyruvate uptake by mesophyll and bundle sheath chloroplasts of a $\mathrm{C}_{4}$ plant, Panicum miliaceum L. Plant and Cell Physiology. 1987;28(1):1-10. https://doi.org/10.1093/oxfordjournals.pcp.a077263

26. Nakamoto H, Edwards GE. Effect of adenine nucleotides on the reaction catalysed by pyruvate, orthophosphate dikinase in maize. Biochemica et Biophysica Acta (BBA)-General Subjects. 1987; 924(2):360-68. https://doi.org/10.1016/03044165(87)90034-1

27. Zhu XG, Wang Y, Ort DR, Long SP. e-photosynthesis: a comprehensive dynamic mechanistic model of $\mathrm{C}_{3}$ photosynthesis: from light capture to sucrose synthesis. Plant, Cell \& Environment. 2013;36(9):1711-27. https://doi.org/10.1111/pce.12025
28. Schaffer AA, Quick WP. Sucrose Metabolism in Sources and Sinks. In Photoassimilate Distribution Plants and Crops Source-Sink Relationships. Routledge, 2017. p. 115-58.

29. Abogadallah GM. Differential regulation of photorespiratory gene expression by moderate and severe salt and drought stress in relation to oxidative stress. Plant Science. 2011; 180(3):540-47. https://doi.org/10.1016/j.plantsci.2010.12.004

30. Busi R, Vila-Aiub MM, Beckie HJ, Gaines TA, Goggin DE, Kaundun SS, Lacoste M, Neve P, Nissen SJ, Norsworthy JK, Renton M. Herbicide-resistant weeds: from research and knowledge to future needs. Evolutionary Applications. 2013; 6(8):1218-21. https://doi.org/10.1111/eva.12098

31. Doubnerová $\mathrm{V}$, Ryšlavá $\mathrm{H}$. What can enzymes of $C_{4}$ photosynthesis do for $C_{3}$ plants under stress? Plant Science. 2011;180(4):575-83. https://doi.org/10.1016/j.plantsci.2010.12.005

32. Jiao Y, Lau OS, Deng XW. Light-regulated transcriptional networks in higher plants. Nature Reviews Genetics. 2007;8(3):217-30. https://doi.org/10.1038/nrg2049

33. Mishra S, Joshi B, Dey P, Pathak H, Pandey N, Kohra A. CCM in photosynthetic bacteria and marine alga. Journal of Pharmacognosy and Phytochemistry. 2018;7(6):928-37.

34. Bergamini CM, Gambetti S, Dondi A, Cervellati C. Oxygen, reactive oxygen species and tissue damage. Current Pharmaceutical Design. 2004;10(14):1611-26. https://doi.org/10.2174/1381612043384664

35. Sarkar B, De AK, Saha I, Ghosh A, Debnath SC, Adak MK. Amelioration with titanium dioxide nanoparticle for regulation of oxidative stress in maize (Zea mays L.). The Journal of Microbiology, Biotechnology and Food Sciences. 2019;9(2):320-29. https://doi.org/10.15414/jmbfs.2019.9.2.320-329 